\title{
Dermoid and Epidermoid Cysts: A Case Series
}

\author{
${ }^{1}$ Tanvi Patel, ${ }^{2}$ Shilpa Patel, ${ }^{3}$ Jigna Pathak, ${ }^{4}$ Niharika Swain, ${ }^{5}$ Mitesh Jain, ${ }^{6}$ Ketki J Shirke
}

\begin{abstract}
Epidermoid and dermoid cysts of the skin are commonly encountered in surgical practice. Epidermoid cysts and dermoid cysts are uncommon developmental and acquired cystic malformations. Dermoid and epidermoid cysts occur less frequently in the head and neck region. These cysts constitute for 1.6 to $6.9 \%$ of all cysts in the head and neck area. However, the intraoral epidermoid and dermoid cysts are very rare and account for less than $0.01 \%$ of all cysts in the oral cavity. Here we present a series of five cases of dermoid and epidermoid cysts. The study was carried out on histopathologically diagnosed cases of epidermoid cysts and dermoid cysts were retrieved from the archives of Department of Oral and Maxillofacial Pathology from a period of 2015 to 2018 . Four cases of epidermoid cysts and one case of dermoid cyst were reported. This article mentions the distinguishing histopathological features of these two cysts which help the surgeon to carry out a definitive treatment protocol.
\end{abstract}

Keywords: Dermoid cyst, Epidermoid cyst, Malignant transformation Oral, Rare.

How to cite this article: Patel T, Patel S, Pathak J, Swain N, Jain M, Shirke KJ. Dermoid and Epidermoid Cysts: A Case Series. J Contemp Dent 2018;8(3):153-156.

Source of support: Nil

Conflict of interest: None

\section{BACKGROUND}

Epidermoid and dermoid cysts of the skin are commonly encountered in surgical practice. However, the epidermoid and dermoid cysts are rarely encountered within the oral cavity. In 1955, the concept of the dermoid cyst was updated by Meyer. Three histological variants were given which were: a true dermoid cyst, the epidermoid cyst, and the teratoid variant. ${ }^{1}$ Epidermoid cysts and dermoid cysts are uncommon developmental and acquired cysticmal formations. The dermoid cysts are more often congenital whereas the epidermoid cysts are most often acquired ones. ${ }^{2}$ Epidermoid cysts are rare, slowly growing, benign cysts. Around $7 \%$ of the cysts are

\footnotetext{
1,5,6 Postgraduate Student, ${ }^{2}$ Professor and Head, ${ }^{3}$ Professor, ${ }^{4}$ Reader

${ }^{1-6}$ Department of Oral Pathology and Microbiology, Mahatma Gandhi Mission`s Dental College and Hospital, Kamothe, Navi Mumbai, India

Corresponding Author: Tanvi Patel, Postgraduate Student, Department of Oral Pathology and Microbiology, Mahatma Gandhi Mission`s Dental College and Hospital, Kamothe, Navi Mumbai, India email: drtanvipatel92@gmail.com
}

located in the head and neck region. ${ }^{3}$ They are derived from abnormally growing ectodermal tissue. These cysts grow anywhere in the body. Histopathologically, they are lined by stratified squamous epithelium and lumen without skin appendages. ${ }^{4}$ Dermoid cysts of the head and neck are believed to represent sequestration of the epidermis along the lines of embryonic closure. They are the developmental cysts usually occurring during the third to fifth week of embryological development. ${ }^{5}$ Lesions occur on the scalp, glabella and the bridge or dorsum of the nose and they usually present as solitary lesions. Histologically the dermoid cyst shows keratinized stratified squamous epithelium along with sebaceous glands, sweat glands, and hair follicles.

Dermoid and epidermoid cysts occur less frequently in the head and neck region. These cysts constitute for 1.6 to $6.9 \%$ of all cysts in the head and neck area. ${ }^{6}$ However the intraoral epidermoid and dermoid cysts are very rare and account for less than $0.01 \%$ of all cysts in the oral cavity. ${ }^{7}$

In this article, we present a case series emphasizing on the differentiating histological features of the epidermoid cyst and dermoid cyst.

\section{SERIES OF CASE REPORTS}

A total of five histopathologically diagnosed cases of epidermoid cysts and dermoid cysts, retrieved from the archives of Dept. of Oral and Maxillofacial Pathology from a period of 2015 to 2018 were evaluated. Four cases of epidermoid cysts and one case of dermoid cyst were studied. All the cases were re-evaluated clinicopathologically. Both macroscopic and microscopic histopathological features were noted (Table 1). The microscopic features were evaluated according to the type of keratinization present, features present in the lining and the connective tissue wall, presence of epidermis and skin appendages (Figs 1 to 5 ).

\section{DISCUSSION}

The developmental cutaneous cysts occurring in the head and neck region are the dermoid and epidermoid cysts. However, these cysts rarely occur intraorally. A clear distinction has been made from the common inclusion cysts of the skin which are a sebaceous cyst, milia, epidermal cyst or trichilemmal cyst. The terms sebaceous cyst and milia are used clinically and no longer have any pathological connotation. Epidermal cysts and trichilemmal 
Table 1: Contents show the gross features, histopathological features and the histopathological diagnosis of the cases

\begin{tabular}{|c|c|c|c|c|c|}
\hline $\begin{array}{l}\text { Case } \\
\text { No }\end{array}$ & $\begin{array}{l}\text { Age/ } \\
\text { Sex }\end{array}$ & Site & Gross Features & Histopathological Features & $\begin{array}{l}\text { Histopatho- } \\
\text { logical Diagnosis }\end{array}$ \\
\hline 1. & $27 / F$ & $\begin{array}{l}\text { Left sublingual } \\
\text { region }\end{array}$ & $\begin{array}{l}\text { Single bit with smooth } \\
\text { surface, oval shaped and } \\
\text { grey color measuring approx. } \\
5.7 \times 4 \times 1.3 \mathrm{cms}\end{array}$ & $\begin{array}{l}\text { Cystic lumen showing degenerated keratin with few } \\
\text { keratin flakes. Orthokeratinised cystic epithelial lining } \\
\text { with prominent granular cell layer surrounded by a } \\
\text { capsule with no inflammation. }\end{array}$ & Epidermoid cyst \\
\hline 2. & $43 / \mathrm{M}$ & $\begin{array}{l}\text { Right cheek } \\
\text { region posterior } \\
\text { to commissure of } \\
\text { mouth }\end{array}$ & $\begin{array}{l}\text { Single bit with smooth } \\
\text { surface, oval shape, grey } \\
\text { balck color measuring } \\
\text { approx. } 2.5 \times 2.0 \times 2.0 \mathrm{cms}\end{array}$ & $\begin{array}{l}\text { Cystic lumen with degenerated keratin and few } \\
\text { foci of keratin flakes. Thin orthokeratinised cystic } \\
\text { epithelial lining surrounded by a sparse connective } \\
\text { tissue capsule. }\end{array}$ & Epidermoid cyst \\
\hline 3. & $17 / M$ & $\begin{array}{l}\text { Right parotid } \\
\text { region }\end{array}$ & $\begin{array}{l}\text { Single bit with a smooth } \\
\text { surface, round to oval } \\
\text { shape, the grey-white color } \\
\text { measuring approx } 2.5 \mathrm{cms} \text { in } \\
\text { diameter }\end{array}$ & $\begin{array}{l}\text { Cystic lumen filled with flaky keratin, lined by a } \\
\text { thin layer of orthokeratinized stratified squamous } \\
\text { epithelium. The connective tissue wall shows } \\
\text { condensed fibrous tissue, hemorrhage and focal } \\
\text { areas of inflammatory cell aggregate }\end{array}$ & Epidermoid cyst \\
\hline 4. & $35 / F$ & Cheek & $\begin{array}{l}\text { Single bit with an irregular } \\
\text { surface, rhomboidal in } \\
\text { shape, the black color } \\
\text { measuring about } 1.8 \times 1.2 \mathrm{x} \\
0.6 \mathrm{cms} \text {. }\end{array}$ & $\begin{array}{l}\text { Cystic lumen with abundant keratin flakes lined by } \\
\text { the orthokeratinized stratified squamous epithelium } \\
\text { of varying thickness. The connective tissue capsule } \\
\text { shows dense collagen with a subepithelial layer of } \\
\text { chronic inflammatory cell infiltration. }\end{array}$ & Epidermoid cyst \\
\hline 5. & $18 / F$ & $\begin{array}{l}\text { Left infraorbital } \\
\text { region }\end{array}$ & $\begin{array}{l}\text { Single bit with the smooth } \\
\text { surface along with superficial } \\
\text { skin attached, lobulated } \\
\text { shape, grey-white in color } \\
\text { measuring approx. } 2.5 \times 1.5 \\
\times 1.0 \mathrm{cms}\end{array}$ & $\begin{array}{l}\text { Presence of surface keratinized epithelium with } \\
\text { sebaceous glands and hair follicles. Lesional tissue } \\
\text { showed a cystic lumen with degenerated keratin } \\
\text { and abundant keratin flakes. Six to eight layer thick } \\
\text { orthokeratinized stratified squamous epithelium } \\
\text { with prominent granular cell layer surrounded by a } \\
\text { capsule lacking inflammation. }\end{array}$ & Dermoid cyst \\
\hline
\end{tabular}

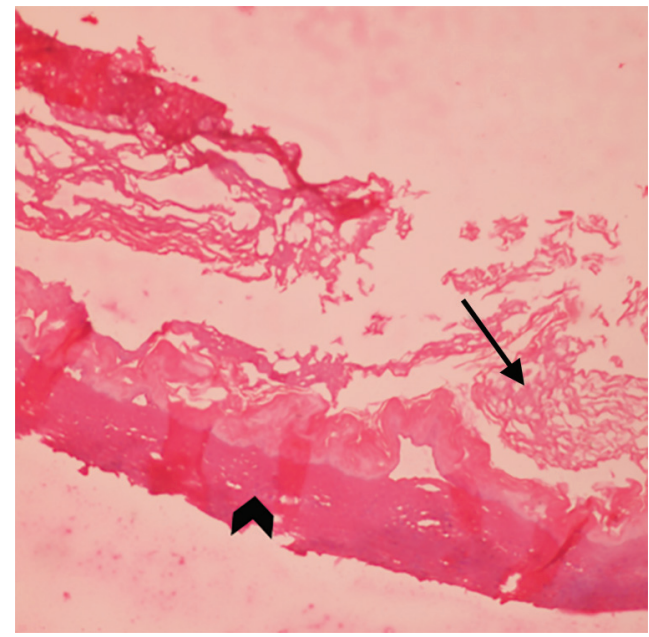

Fig 1: Photomicrograph of the soft tissue section shows a cystic lumen filled with flaky keratin(arrow), lined by a thin layer of orthokeratinized stratified squamous epithelium and connective tissue wall (arrowhead)showing condensed fibrous tissue, hemorrhage and focal areas of inflammatory cell aggregate (Epidermoid Cyst) (H\&E stain, magnification 100X)

cysts have been established as different entities with individual characteristic clinical and pathological features. ${ }^{8}$

Clinically, the dermoid and epidermoid cysts present as soft and nodular lesions with a sessile base. These cysts are classified based on whether they are lined by simple squamous epithelium without skin adnexa as an epidermoid cyst, or the skin adnexa found in the cystic wall as a dermoid cyst. ${ }^{9}$ The dermoid and epidermoid cysts are congenital and acquired. ${ }^{10}$ These are the developmental cysts which form as a result of sequestration of skin along lines of embryonic closure. ${ }^{11}$ The embryonic cells

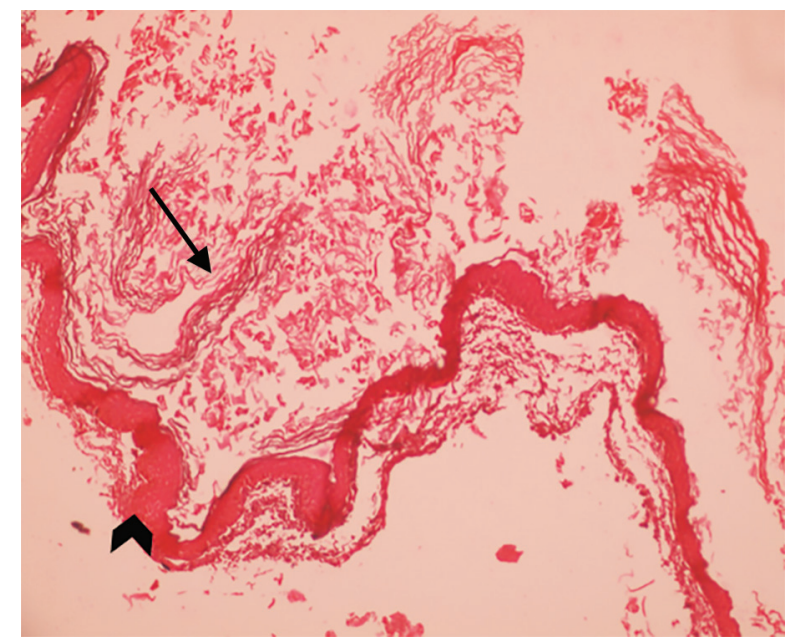

Fig 2: Photomicrograph of the soft tissue section shows a cystic lumen with degenerated keratin and few foci of keratin flakes (arrow) lined by thin orthokeratinized cystic epithelial lining with a prominent granular layer surrounded by a sparse connective tissue capsule (arrowhead) (Epidermoid Cyst) (H\&E stain, magnification 100X)

of the 1st and 2nd branchial arch are the origins of the dermoid cysts. These cysts arise from entrapped midline ectodermal tissue lined by epidermis with skin appendages present in the fibrous wall. ${ }^{8}$ The acquired ones are caused as a result of traumatic or iatrogenic implantation of epithelial cells into the surrounding tissues. ${ }^{12}$ The area of occurrence is mostly on the head, mainly around the eyes and occasionally on the neck. They are often seen to be adherent to the periosteum when present on the head. They usually measure around 1 to $4 \mathrm{cms}$ in diameter. ${ }^{11}$ In case of intraoral lesions, the midline of the floor of the 


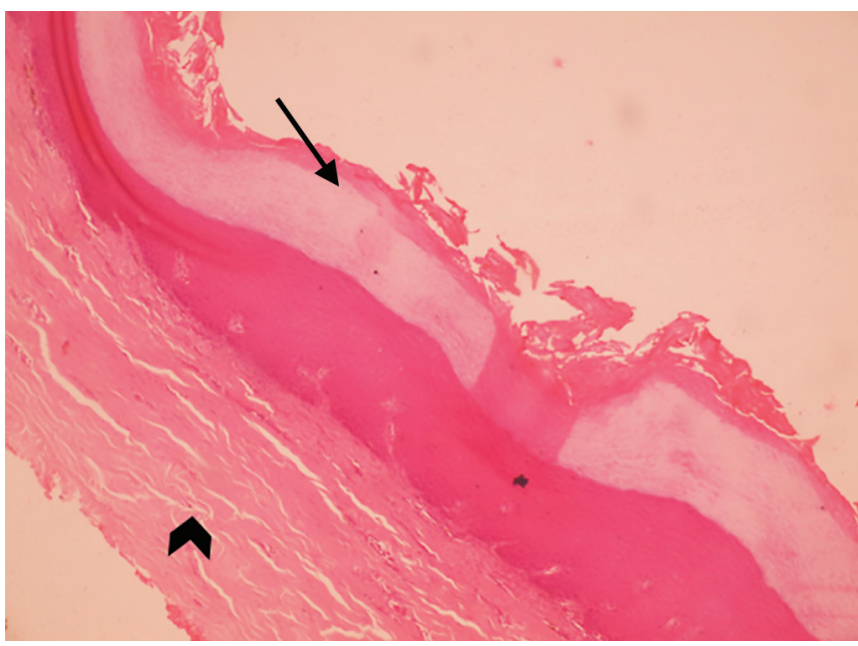

Fig 3: Photomicrograph of the soft tissue section shows a cystic lumen with sheets of keratin in a lamellar pattern (arrow) lined by orthokeratinized stratified squamous epithelium of varying thickness with the connective tissue capsule (arrowhead) showing dense collagen (Epidermoid Cyst) (H\&E stain, magnification 100X)

mouth is the most common site of occurrence. ${ }^{8}$ The statistics which were quoted from the Mayo Clinic indicated that out of 1495 'dermoid' cysts seen in an adult population over 26 years, 103 , i.e. $6.9 \%$ occurred in the head and neck region and only 24 , i.e. $1.6 \%$ of the cysts were found in the floor of the mouth. Most of these reported cases were usually in the midline, occurring in the sublingual region. These lesions are also seen to occur rarely on the tongue, lips and intraosseously.

Among the cases reported in our department, only one case of the dermoid cyst was reported in the period of three years (2015 to 2018). However, the lesion was an extraoral one, present in the left infraorbital region. It is stated that although the cysts are present at birth (Yoshimura et al., and Yeschua et al.) and in elderly patients, the majority lesions occur between the ages of 15 and 35 years. Longo et al. reported cases with a male: female ratio of 3:1. King et al. in 1994 also saw a male predilection with respect to dermoid cysts.

Histologically, the dermoid cysts as compared to epidermal cysts are lined by epidermis that possesses various fully matured epidermal appendages. Dermoid cysts contain hair follicles that project into the lumen of the skin. The dermis is usually seen to contain sebaceous glands. ${ }^{11}$ In our case, the dermoid cyst grossly had a lobulated appearance with a smooth surface and attached superficial skin. In the dermoid cyst, the surface keratinized stratified squamous epithelium showed sebaceous glands and hair follicles. The lesional tissue showed a cystic lumen with the presence of abundant keratin flakes. The 6 to 8 cell thick cystic epithelial lining showed a prominent granular cell layer and was surrounded by a capsule with no inflammation present.

An epidermoid cyst is also a developmental cyst which can be follicular or non-follicular in origin. The cyst having a follicular origin is seen to develop from the

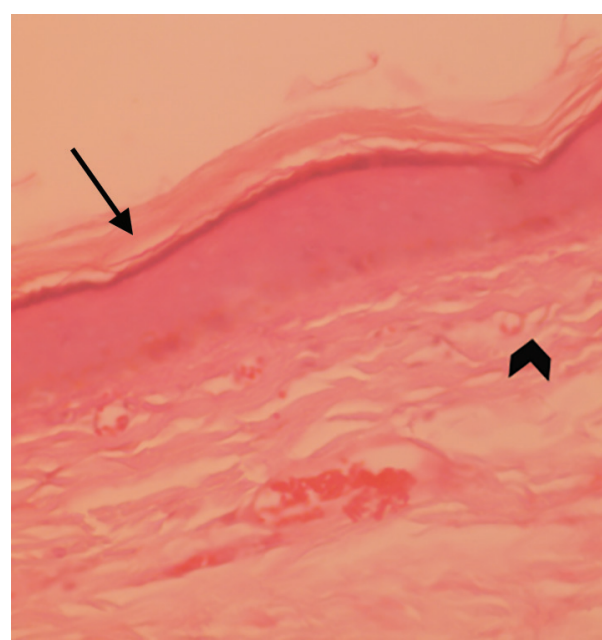

Fig 4: Photomicrograph of the soft tissue section shows the cystic lumen showing keratin arranged in a lamellar pattern (arrow) and few keratin flakes (arrowhead) lined by orthokeratinized cystic epithelial lining with prominent granular cell layer surrounded by a capsule with no inflammation (Epidermoid Cyst) (H\&E stain, magnification 100X)

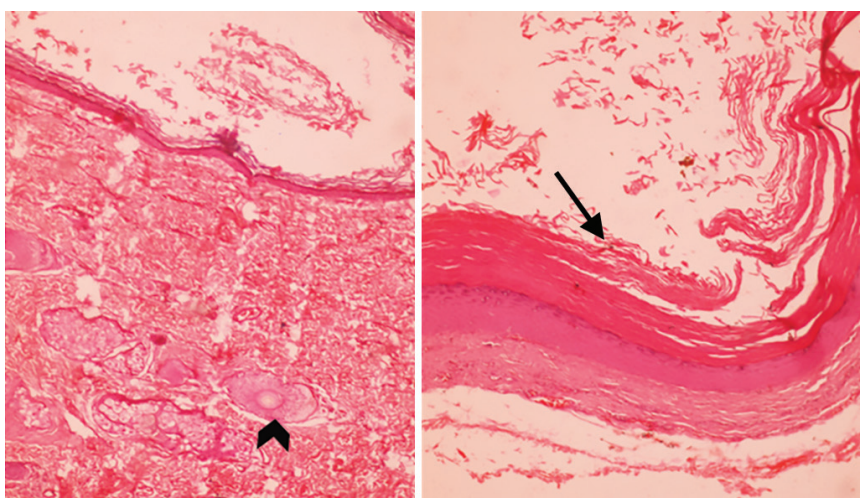

Fig 5: Photomicrograph (10x) of the soft tissue section shows the presence of surface keratinized epithelium with sebaceous glands and hair follicles (arrowhead). The lesional tissue shows a cystic lumen filled with degenerated keratin and abundant keratin flakes (arrow) lined by a 6 to 8 layer thick orthokeratinised stratified squamous epithelium with prominent granular cell layer surrounded by a capsule lacking inflammation (Dermoid Cyst) (H\&E stain, magnification 10X)

follicular infundibulum. It is seen in relation to the hair follicle. The cyst with a non-follicular origin (acquired) is a result of traumatic implantation. The term implantation keratinizing epidermoid cysts or epidermoid inclusion cyst can be used in such cases. ${ }^{7}$ For the cysts to form, a cascade of events such as traumatic epithelial implantation followed by epithelial proliferation with minimal inflammation is required. However, these events are very uncommon, and thus it can explain the rarity of these lesions. ${ }^{7}$ The age of occurrence of epidermoid cysts is usually between 15 to 35 years but can be seen in all age groups. The patients reported to us with the lesion were in the same age range except for one patient whose age was 42 years.

Epidermoid cysts are lined by the epidermis but without appendages. The origin of dermoid and epidermoid cysts of the floor of the mouth, like other developmental cysts, is controversial. After examining 
and discarding a number of concepts, Seward in 1965 suggested that between the contributions from the mandibular arches to the tongue anteriorly, is the most likely site for their origin. However, this implies an endodermal derivation which was unlikely for a structure that contains skin adnexa. Ettinger and Manderson in 1973 suggested that implantation keratinizing epidermoid cysts may occur in other parts of the mouth as a result of trauma. In 1965, Seward believed that dermoid and epidermoid cysts of the midline of the floor of the mouth always originate above the mylohyoid muscle. Allard in 1982, differentiated between a sublingual or genioglossal type which is located between the geniohyoid muscle and the oral mucosa, and a geniohyoid (submental) type which is positioned between the geniohyoid and mylohyoid muscle. In the review of King et al. in 1994, $52 \%$ of cases were recorded as sublingual, $26 \%$ of cases as submental and $6 \%$ of cases as submandibular. The remaining $16 \%$ of cases occupied more than one space. ${ }^{8}$

Histologically, in young epidermoid cysts several layers of squamous and granular epithelium can be usually recognized whereas, in the older epidermal cysts, the wall appears to be markedly atrophic and may consist of only one or two rows of flattened cells. The cyst contains horny material arranged in laminated layers. Presence of melanin pigmentation, melanocytes and melanophages can also be observed in some cases. ${ }^{11}$ A distinct granular layer and lamellated keratin without calcification are a characteristic feature of this cyst. ${ }^{13}$ In our cases, the sites of occurrence were the cheeks, sublingual and right parotid (epidermoid cyst). The histological features observed in our cases were in accordance with the above histological features with all cases showing orthokeratinization. The cystic lumen showed the presence of few foci of keratin flakes. Two to three cell layer epithelium with the presence of a prominent granular cell layer was observed in all our cases. Two cases also showed melanin pigmentation. Chronic inflammatory cell infiltration was also observed in two cases of the epidermoid cyst. Thus all the cysts were seen to have individual distinct characteristics. After the follow up of the patient, no recurrence of the lesions has been observed.

The treatment for these cysts is surgical excision. Once excised surgically, the recurrence of these cysts is very less frequent. Intraorally occurring dermoid and epidermoid cysts are usually asymptomatic. They can show acute symptoms when secondarily infected. There have been some case reports showing the malignant transformation of these cysts. Malignant transformation is seen in $2 \%$ of the cases of the dermoid cysts ${ }^{14}$ and $0.011 \%$ to $0.045 \%$ cases of the epidermoid cysts. ${ }^{15}$ Ikeda et al. in 1990, reported a case of basal cell carcinoma arising from the epidermoid cyst. Lopez-Rios et al. in 1999, reported a case of squamous cell carcinoma arising from the connective tissue wall of the epidermoid cyst. Devine et al. in 2000, reported a case of a dermoid cyst in the sublingual region showing the carcinomatous transformation. Thus the diagnosis of these cysts should be made after ruling out other developmental, infectious and malignant lesions.

\section{CONCLUSION}

Thus to conclude it is seen that the intraoral occurrence of the dermoid and an epidermoid cyst is a very rare entity. Both the cysts can undergo malignant transformation. However, the rate of malignant transformation in a dermoid cyst is higher than that if an epidermoid cyst. Thus both these cysts should be distinguished based on their histopathological features to rule out the malignant transformation. This will, therefore, help the surgeon to carry out a definitive treatment protocol.

\section{REFERENCES}

1. Shenoy N, Poojary D, Mohan R, Naik R, Baliga M. "Epidermoid cyst of the floor of the mouth," National Journal of Maxillofacial Surgery. 2014;5(1):79-83.

2. Cho.Y, Lee.D. "Clinical Characteristics of Idiopathic Epidermoid and Dermoid Cysts of the Ear," J Audiol Otol, 2017 Jul; 21(2):77-80

3. Dutta M, Saha J, Biswas G, Chattopadhyay S, Sen I, Sinha R. "Epidermoid Cysts in Head and Neck: Our Experiences, with Review of Literature," Indian J Otolayngol Head Neck Surg, 2013 Jul;65(1):14-21.

4. Janarthanam J, Mahadevan S., " Epidermoid Cyst of Submandibular Region," J Oral Maxillofac Pathol, 2012 Sep-Dec; 16(3): 435-437.

5. Makhija D, Sisodiya N, Shah H, Waghmare M. "Cystic Congenital Scalp Inclusion Dermoid: A Case Report," Dev Period Med, 2016;4:287-288.

6. Jham BC, Duraes GV, Jham AC, Santos CR. "Epidermoid Cyst of the Floor of the Mouth: A Case Report," JCDA. 2007; 73: 525-528.

7. Kini YK, Kharkar VR, Rudagi BM, Kalburge JV. “An Unusual Occurrence of Epidermoid Cyst in the Buccal Mucosa: A Case Report with Review of Literature," J. Maxillofac Oral Surg, 2013;12(1):90-93.

8. Shear M, Speight P. Cysts of the Oral and Maxillofacial Regions, 4th Edition: 181-183

9. Sabhalok SS, Shetty LS, Sarve PH, Setiya SV, Bharadwaj SR. "Epidermoid and Dermoid Cysts of the Head and Neck Region," PlastAesthet Res, 2016;3:347-350.

10. Dillon JR, Avillo AJ, Nelson BL. " Dermoid Cyst of the Floor of the Mouth", Head Neck Pathol, 2015 Sep;9(3):376-378.

11. Lever's Histopathology of the Skin, Tenth Edition, 800-804

12. Erich JB. "Sebaceous, mucous, dermoid and epidermoid cysts," Am J Surg. 1940;50:672-677.

13. Rosai J., Rosai and Ackerman's Surgical Pathology, Ninth Edtion. 1:151-152.

14. Sanghera P, El Modir A, Simon J. Malignant transformation within a dermoid cyst: a case report and literature review. Archives of gynecology and obstetrics. 2006 Jun 1;274(3):178.

15. Rathna S. "Epidermal cyst with malignant transformation: A case report," Journal of Diagnostic Pathology and Oncology, 2017;2(1):13-14. 